\title{
ANALISIS REGRESI PANEL PADA PEMODELAN TINGKAT KEMATIAN BAYI DI PROVINSI SULAWESI SELATAN
}

\author{
Syafruddin Side ${ }^{1}$, Sukarna $^{1}$, dan Raihana Nurfitrah ${ }^{1, a)}$ \\ ${ }^{1}$ Jurusan Matematika FMIPA Universitas Negeri Makassar, 90224 \\ a) rararaihanarara@gmail.com
}

\begin{abstract}
Abstrak. Penelitian ini membahas mengenai estimasi parameter model regresi data panel pada pemodelan tingkat kematian bayi di Provinsi Sulawesi Selatan dari tahun 2014 sampai dengan 2015. Data yang digunakan adalah data sekunder dari Dinas Kesehatan Provinsi Sulawesi Selatan yang berupa jumlah kematian bayi, berat bayi lahir rendah, persalinan yang ditolong oleh tenaga kesehatan, penduduk miskin, bayi yang diberi ASI ekslusif dan rumah tangga berperilaku bersih sehat di seluruh Kabupaten/Kota di Provinsi Sulawesi Selatan tahun 2014-2016. Analisis data dilakukan dengan menggunakan penghitungan manual dan dengan menggunakan software EViews 9. Pembahasan dimulai dari melakukan estimasi parameter model regresi data panel, menentukan model regresi data panel terbaik, , menguji asumsi model regresi data panel, pengujian signifikansi parameter dan interpretasi model regresi. Dalam penelitian ini diperoleh kesimpulan yaitu estimasi model regresi data panel terbaik dengan pendekatan fixed effect model
\end{abstract}

Kata kunci : Regresi Data Panel, Kematian Bayi, Fixed Effect Model, Least Square Dummy Variable.

\begin{abstract}
This research discusses about parameter estimation of panel data regression model of infant mortality level modelling in South Sulawesi from 2014 to 2015. The data used were secondary data from Dinas Kesehatan Provinsi Sulawesi Selatan in the form of number of infant mortality, low weight of infant, childbirth rescued by health workers, poor population, infants who were given exclusive breast milk and household that behaves well in the whole district/town in South Sulawesi year 2014-2016. Data analysis was performed using the calculation manually and by using EViews 9 software. The discussion started from doing parameter estimation of panel data regression model, determining the best panel data regression model, testing the assumption of panel data regression model, testing the signification of parameter and interpretation of regression model. Conclusion of this research are the estimation of regression model is the best panel data regression model with fixed effects model approach.
\end{abstract}

Keywords :Panel Data Regression, Infant Mortality, Fixed Effect Model, Least Square Dummy Variable

\section{PENDAHULUAN}

Perkembangan ilmu statistik dalam kehidupan sehari-hari menyebabkan penemuan-penemuan baru untuk menganalisis suatu masalah, salah satunya adalah analisis regresi. Analisis regresi merupakan analisis yang digunakan untuk menjelaskan keterkaitan hubungan antara suatu variabel bebas (independent) terhadap variabel terikat (dependent) yang dapat dinyatakan sebagai bentuk model matematis. Salah satu analisis regresi yang tepat digunakan adalah regresi data panel. Data panel merupakan kombinasi dari data cross sectional dan time series (Gujarati, 2004). Penggunaan analisis regresi panel saat ini pada bidang kesehatan masih tergolong sedikit oleh karena itu maka akan diterapkan analisis regresi data panel pada bidang kesehatan. Dalam pengaplikasian regresi data panel yang diinginkan, studi kasus yang diambil adalah mengenai kematian bayi. 
Angka Kematian Bayi (AKB) di Provinsi Sulawesi Selatan tergolong masih tinggi. Dari hasil pengumpulan data profil kesehatan tahun 2014 jumlah kematian bayi menjadi 1.056 bayi atau 7.23 per 1000 kelahiran hidup maka masih perlu peran dari semua pihak yang terkait dalam rangka penurunan angka tersebut sehingga salah satu target pemerintah yaitu (Milinium Development Goals) MDGs khususnya penurunan angka kematian dapat tercapai.

Beberapa peneliti telah melakukan penelitian tentang Analisis Faktor-faktor pengaruh Angka Kematian Bayi di berbagai wilayah di Indonesia, diantaranya yaitu Ardiyanti dan Puryadi (2010) mengkaji tentang pemodelan Angka Kematian Bayi di Provinsi Jawa Timur dengan menggunakan metode Geographically Weighted Poisson Regression (GWPR) sebagai metode statistik untuk menganalisis data spasial dari proses yang non stasioner, dan Sastri (2015) mengkaji tentang pembentukan model Angka Kematian Bayi di Indonesia dengan metode Regresi Logistik.

Oleh karena itu, pada penelitian ini akan dilakukan pemodelan untuk mengetahui faktor-faktor yang mempengaruhit ingkat kematian bayi yang ada di wilayah Sulawesi Selatan dari tahun 2014 hingga tahun 2016. Regresi data panel ini digunakan karena regresi data panel merupakan gabungan antara data cross section dan data time series, sehingga akan diperoleh informasi yang lebih lengkap.

\section{Regresi Data Panel}

Regresi data panel merupakan analisis menggunakan regresi namun data yang dipakai adalah memadukan data cross sectional dan time series. Model regresi data panel dinyatakan dalam persamaan (1).

$$
Y_{i t}=\beta_{0 i t}+\beta_{k} X_{i t}+e_{i t}
$$

$$
\begin{array}{lll}
\text { Keterangan : } & Y_{i t} & \text { : unit cross section ke- } i \text { periode waktu ke- } t \\
\beta_{0} & : \text { intersep } \\
\beta_{k} & : \text { koefisien slope } \\
X_{i t} & : \text { variabel bebas } \\
e_{i t} & : \text { komponen error } \\
i & : \text { jumlah unit individu, dimana } i=1,2, \ldots, 4 \\
t & \text { : jumlah unit waktu, dimana } i=1,2,3 \\
k & : \text { jumlah variabel bebas, dimana } k=1,2, \ldots, 5
\end{array}
$$

\section{Model Regresi Data Panel}

Data panel merupakan gabungan dari data cross section dan data time series sehingga data yang dipakai untuk pengamatan sangat banyak sehingga perlu adanya teknik dalam menggunakan data panel. Dalam regresi data panel, teknik yang dimaksud merupakan beberapa model yang bisa dilakukan untuk analisis (Adelina, 2016). Model regresi data panel yang dimaksud adalah sebagai berikut:

1. Common Effect Model

Commont Effect Model (CEM) menggabungkan data cross section dengan time series dan menggunakan metode Ordinary Least Square (OLS) untuk mengestimasi model data panel tersebut (Widarjono, 2009).

Secara umum, persamaan modelnya dituliskan pada persamaan (2).

$$
Y_{i t}=\beta_{0}+\beta_{k} X_{i t}+e_{i t}
$$




\section{Fixed Effect Model}

Fixed Effect Model adalah metode regresi yang mengestimasi data panel dengan menambahkan variabel dummy Secara umum, persamaan modelnya dituliskan pada persamaan (3).

$$
Y_{i t}=\beta_{0_{i}}+\beta_{k} X_{i t}+e_{i t}
$$

3. Random Effect Model

Random Effect Model adalah metode regresi yang mengestimasi data panel metode generalized least square. Secara umum, persamaan modelnya dituliskan pada persamaan (4).

$$
Y_{i t}=\beta_{0_{i}}+\beta_{k} X_{i t}+U_{i}+e_{i t}
$$

\section{Metode Estimasi Regresi Data Panel}

Metode estimasi regresi data panel ini bertujuan untuk memilih dari ketiga model (common effect, fixed effect dan random effect model) regresi yang tepat atau sesuai dengan tujuan penelitian. Metode estimasi yang dimaksud yaitu:

\section{Uji Chow}

Pengujian ini dilakukan untuk memilih Common Effect Model atau Fixed Effect Model, dengan hipotesis sebagai berikut

$H_{0}$ : Model yang digunakan Common Effect Model

$H_{1}$ : Model yang digunakan Fixed Effect Model

Statistik uji

$$
F=\frac{[R R S-U R S S] /(n-1)}{U R S S /(n T-n-K)}
$$

Keterangan : $n \quad:$ Jumlah individu (cross section)

T : Jumlah periode waktu (time series)

$K \quad$ : Jumlah variabel bebas

RRS : Jumlah error kuadrat dari estimasi common effect

URSS : jumlah error kuadrat dari estimasi fixed effect

Jika nilai $F>F_{(n-1),(n T-n-K)}$ atau $p$-value $<\alpha$ maka $H_{0}$ ditolak yang artinya model fixed effect yang lebih baik digunakan.

2. Uji Hausman

Pengujian ini dilakukan untuk memilih Fixed Effect Model atau Random Effect Model, dengan hipotesis sebagai berikut

$H_{0}$ : Model yang digunakan Random Effect Model

$H_{1}$ : Model yang digunakan Fixed Effect Model

Statistik uji

$$
\begin{gathered}
W=\hat{q}^{\prime}\left[\operatorname{var}\left(\hat{q}^{\prime}\right)\right]^{-1} \hat{q} \\
\Leftrightarrow W=\left(\hat{\beta}_{F E M}-\hat{\beta}_{R E M}\right)^{\prime}\left[\operatorname{var}\left(\hat{\beta}_{F E M}-\hat{\beta}_{R E M}\right)\right]^{-1}\left(\hat{\beta}_{F E M}-\hat{\beta}_{R E M}\right)
\end{gathered}
$$

Keterangan : $\quad \hat{\beta}_{F E M}$ : vektor estimasi slope FEM

$$
\hat{\beta}_{R E M} \text { : vektor estimasi slope REM }
$$

3. Uji Lagrange Multiplier

Pengujian ini dilakukan untuk memilih Random Effect Model atau Common Effect Model, dengan hipotesis sebagai berikut

$H_{0}$ : Model yang digunakan Common Effect Model 
$H_{1}$ : Model yang digunakan Random Effect Model

Statistik uji

$$
L M=\frac{n T}{2(T-1)}\left[\frac{\sum_{i=1}^{n}(T \hat{e} i)^{2}}{\sum_{i=1}^{n} \sum_{t=1}^{T} \hat{e}_{i t}^{2}}-1\right]^{2}
$$

\section{Uji Asumsi Regresi Data Panel}

Menurut Yudiatmaja dalam Pangestika (2015), model regresi data panel dapat disebut sebagai model yang baik jika model tersebut memenuhi kriteria Best, Linear, Unbiased, dan Estimator (BLUE). BLUE dapat dicapai bila memenuhi asumsi klasik. Asumsi klasik yang dimaksud adalah sebagai berikut.

1. Uji Normalitas

Data-data pengamatan dari sampel yang diambil perlu diuji kembali apakah berasal dari populasi yang berdistribusi normal atau tidak. Hipotesis penelitiannya adalah sebagai berikut :

$H_{0}$ : Residual berdistribusi normal

$H_{1}$ : Residual tidak berdistribusi normal

Untuk menguji normalitas maka digunakan Uji Jarque-Bera. Rumus dalam perhitungan uji Jarque-Bera (JB) adalah :

$$
J B_{\text {hitung }}=N\left[\frac{S_{k}{ }^{2}}{6}+\frac{(K-3)^{2}}{24}\right]
$$

Kriteria uji: $H_{0}$ ditolak jika $J B<X_{(\alpha, 2)}^{2}$ atau $p-$ value $>\alpha$ maka $H_{0}$ diterima yang artinya asumsi kenormalan terpenuhi.

2. Uji Multikolinearitas

Multikolinearitas digunakan untuk menguji suatu model apakah terjadi hubungan yang sempurna atau hampir sempurna antara variabel bebas, sehingga sulit untuk memisahkan pengaruh antara variabel-variabel itu secara individu terhadap variabel terikat. Pengujian ini untuk mengetahui apakah antar variabel bebas dalam persamaan regresi tersebut tidak saling berkorelasi. Beberapa indikator dalam mendeteksi adanya multikolinearitas, diantaranya (Gujarati, 2006):

- Nilai yang terlampau tinggi (lebih dari 0,8 ) tetapi tidak ada atau sedikit $\mathrm{t}$ statistik yang signifikan; dan

- Nilai F-statistik yang signifikan, namun t-statistik dari masing-masin variabel bebas tidak signifikan.

- Untuk menguji multikolinearitas dapat melihat matriks korelasi dari variabel bebas, jika terjadi koefisien korelasi lebih dari 0,80 maka terdapat multikolinearitas (Gujarati, 2006).

3. Uji Heteroskedastisitas

Uji heteroskedastisitas digunakan untuk mengetahui ada atau tidaknya penyimpangan asumsi klasik heteroskedastisitas yaitu adanya ketidaksamaan varian dari residual untuk semua pengamatan pada model regresi. Ada beberapa metode pengujian yang bisa digunakan dalam melihat ada tidaknya permasalahan heteroskedastisitas ini, salah satunya adalah uji glejser. Kriteria pengujian sebagai berikut:

$H_{0}$ : tidak ada gejala heteroskedastisitas

$H_{1}$ : ada gejala heteroskedastisitas

Pengambilan keputusan yang dilakukan yaitu $H_{0}$ diterima tidak ditolak bila $-t_{\text {tabel }}<$ $\left|t_{\text {hitung }}\right|<t_{\text {tabel }}$, berarti tidak terdapat heteroskedastisitas dan ditolak bila $t_{\text {hitung }}>$ $t_{\text {tabel }}$ atau $-t_{\text {hitung }}<-t_{\text {tabel }}$ yang berarti terdapat heteroskedastisitas. 


\section{Uji Signifikansi Parameter}

Uji signifikansi parameter atau uji hipotesis ini berguna untuk memeriksa atau menguji apakah koefisien regresi yang didapat signifikan. Pengujian dilakukan dalam tiga tahap yaitu Uji-F, Uji$\mathrm{T}$ dan Koefisien Determinasi $\left(\left(R^{2}\right)\right.$.

1. Uji Serentak (Uji-F)

Hipotesis dalam uji $\mathrm{f}$ adalah sebagai berikut.

$H_{0}: \beta_{1}=\beta_{2}=\beta_{3}=\cdots=\beta_{k}=0$

$H_{1}$ : Paling tidak ada satu koefisien slope yang $\neq 0$

Statistik uji :

$$
F_{\text {hitung }}=\frac{R^{2} /(n+K-1)}{\left(1-R^{2} /(n T-n-K)\right.}
$$

Kriteria uji: $H_{0}$ ditolak jika $F_{\text {hitung }}>F_{(\alpha, n+K-1, n T-n-K)}$, artinya bahwa hubungan antara semua variabel independen dan variabel dependen berpengaruh signifikan (Gujarati, 2004).

2. Uji Parsial (Uji-T)

Hipotesis dalam uji t adalah sebagai berikut.

$H_{0}: \beta_{j}=0$

$H_{1}: \beta_{j} \neq 0 ; j=0,1,2, \ldots, k$

Uji t didefinisikan sebagai berikut.

$$
t=\frac{b_{j}}{s \cdot e\left(b_{j}\right)}
$$

Nilai t diatas akan dibandingkan dengan nilai t Tabel. Bila ternyata setelah dihitung $\left|t_{\text {hitung }}\right|>t_{\left(\frac{\alpha}{2}, n T-n-K\right)}$, maka nilai t berada dalam daerah penolakan, sehingga hipotesis nol ditolak. Dalam hal ini dapat dikatakan bahwa $\beta_{j}$ statiscally significance (Pangestika, 2015).

3. Koefisien Determinasi $\left(R^{2}\right)$

Nilai Koefisien Determinasi $\left(R^{2}\right)$ ini mencerminkan seberapa besar variasi dari variabel terikat $Y$ dapat diterangkan oleh variabel bebas $X$. Bila nilai Koefisien Determinasi $R^{2}=0$, artinya variasi dari tidak dapat diterangkan oleh sama sekali. Sementara bila $R^{2}=1$, artinya variasi $Y$ secara keseluruhan dapat diterangkan oleh $X$.

Secara matematik $R^{2}$ dapat ditulis sebagai berikut (Jaka, 2014) :

$$
R^{2}=1-\frac{\sum \hat{e}_{i}^{2}}{\sum\left(Y_{i}-\bar{Y}^{2}\right.}
$$

\section{METODE PENELITIAN}

Penelitian ini merupakan penelitian terapan dengan studi kasus pemodelan jumlah kematian bayi di Provinsi Sulawesi Selatan tahun 2014-2016 menggunakan metode analisis regresi data panel, data yang digunakan adalah jumlah kematian bayi, jumlah bayi berat lahir rendah (BBLR), jumlah persalinan yang ditolong tenaga kesehatan, jumlah penduduk miskin, jumlah bayi yang diberi ASI ekslusif dan jumlah rumah tangga berperilaku bersih sehat (PHBS) di Provinsi Sulawesi Selatan dari tahun 2014-2016 yang diperoleh dari Dinas Kesehatan Provinsi Sulawesi Selatan dan Badan Pusat Statistik Provinsi Sulawesi Selatan. 


\section{HASIL PENELITIAN}

\section{Analisis Karakteristik Variabel}

Langkah awal sebelum dilakukan proses pengolahan data adalah melakukan deskriptif statistik. Karaktersitik dari masing-masing variabel prediktor dapat diinformasikan melalui deskriptif statistik yaitu jumlah kematian bayi dan semua variabel bebas yang diduga berpengaruh signifikan terhadap perubahan tingkat kematian bayi di Provinsi Sulawesi Selatan dari tahun 2014 hingga 2016. Deskriptif statistik yang digunakan berupa nilai maksimum, minimum, dan rata-rata dari setiap variabel seperti yang ditampilkan dalam Tabel 1.

TABEL 1. Hasil Analisis Statistika Deskriptif

\begin{tabular}{ccccc} 
Variabel & Mean & Varians & Minimum & Maksimum \\
\hline$Y$ & 40.65278 & 513.2159 & 1.000000 & 103.0000 \\
$X_{1}$ & 203.6111 & 19615.30 & 26.00000 & 842.0000 \\
$X_{2}$ & 6167.458 & 2362533 & 1813.000 & 25585.00 \\
$X_{3}$ & 33.48708 & 315.5940 & 8.020000 & 80.46000 \\
$X_{4}$ & 2450.653 & 3640842 & 539.0000 & 10723.00 \\
$X_{5}$ & 22578.56 & 6839034 & 12.81400 & 160916.0 \\
\hline
\end{tabular}

\section{Model Regresi Data Panel}

1. Common Effect Model

TABEL 2. Hasil Estimasi Model Common Effect

\begin{tabular}{ccccc}
\hline Variable & Coefficient & Std. Error & t-Statistic & Prob. \\
\hline C & 9.199029 & 5.187754 & 1.773220 & 0.0808 \\
X1 & 0.075848 & 0.032668 & 2.321803 & 0.0233 \\
X2 & -0.000135 & 0.001367 & -0.098563 & 0.9218 \\
X3 & 0.885950 & 0.194785 & 4.548349 & 0.0000 \\
X4 & -0.002733 & 0.002498 & -1.093929 & 0.2780 \\
X5 & -0.000271 & 0.000121 & -2.234934 & 0.0288 \\
\hline
\end{tabular}

Dari Tabel 2 tersebut dapat diketahui bahwa variabel $X_{1}, X_{3}$ dan $X_{5}$ memiliki pengaruh secara nyata terhadap variabel respon. Sehingga didapat model sebagai berikut:

$$
\hat{y}_{i t}=\left(9.199029+0.075848 X_{1}+0.885950 X_{3}-0.000271 X_{5}\right)
$$

2. Fixed Effect Model

Dari Tabel 3 tdapat diketahui bahwa variabel $X_{1}, X_{3}$ dan $X_{5}$ memiliki pengaruh secara nyata terhadap variabel respon. Sehingga didapat model sebagai berikut:

$$
\hat{y}_{i t}=\left(9.199029+0.075848 X_{1}+0.885950 X_{3}-0.000271 X_{5}\right)
$$


TABEL 3. Hasil Estimasi Model Fixed Effect

\begin{tabular}{ccccc}
\hline Variable & Coefficient & Std. Error & t-Statistic & Prob. \\
\hline C & 9.199029 & 5.187754 & 1.773220 & 0.0808 \\
X1 & 0.075848 & 0.032668 & 2.321803 & 0.0233 \\
X2 & -0.000135 & 0.001367 & -0.098563 & 0.9218 \\
X3 & 0.885950 & 0.194785 & 4.548349 & 0.0000 \\
X4 & -0.002733 & 0.002498 & -1.093929 & 0.2780 \\
X5 & -0.000271 & 0.000121 & -2.234934 & 0.0288 \\
\hline
\end{tabular}

3. Random Effect Model

TABEL 4. Hasil Estimasi Model Random Effect

\begin{tabular}{ccccc}
\hline Variable & Coefficient & Std. Error & t-Statistic & Prob. \\
\hline C & 13.15306 & 5.048921 & 2.605124 & 0.0113 \\
X1 & 0.031409 & 0.028903 & 1.086726 & 0.2811 \\
X2 & 0.000684 & 0.001278 & 0.534868 & 0.5945 \\
X3 & 0.763455 & 0.188228 & 4.056020 & 0.0001 \\
X4 & -0.001372 & 0.002068 & -0.663452 & 0.5094 \\
X5 & -0.000235 & $9.99 \mathrm{E}-05$ & -2.355783 & 0.0215 \\
\hline
\end{tabular}

Dari Tabel 4 dapat diketahui bahwa variabel $X_{3}$ dan $X_{5}$ memiliki pengaruh secara nyata terhadap variabel respon. Sehingga didapat model sebagai berikut:

$$
\hat{y}_{i t}=\left(13.15306+0.763455 X_{3}-0.000235 X_{5}\right)
$$

\section{Pemilihan Model Regresi Data Panel}

1. Uji Chow

Hasil Uji Chow ditampilkan pada Tabel 5.

TABEL 5. Hasil Analisis Statistika Deskriptif

\begin{tabular}{cccc}
\hline Effects Test & Statistic & d.f. & Prob. \\
\hline Cross-section F & 3.676702 & $(23,43)$ & 0.0001 \\
\hline
\end{tabular}

Dari Tabel 5 diketahui bahwa nilai probabilitas F-Statistik sebesar 0.0001 dan nilai tersebut lebih kecil dari $\alpha(5 \%)$ dengan demikian diperoleh kesimpulan yang sama yaitu $H_{0}$ ditolak. Artinya model fixed effect lebih baik digunakan dibandingkan menggunakan model common effect. Ketika model yang terpilih adalah fixed effect maka perlu dilakukan uji lagi, yaitu uji hausman untuk mengetahui apakah fixed effect model atau random effect model yang paling baik digunakan.

2. Uji Hausman

Hasil Uji Hausman ditampilkan pada Tabel 6. 
TABEL 6. Hasil pemilihan model fixed effect dan random effect

\begin{tabular}{cccc}
\hline Test Summary & Chi-Sq. Statistic & Chi-Sq. d.f. & Prob. \\
Cross-section random & 39.726316 & 5 & 0.0000 \\
\hline
\end{tabular}

Dari hasil uji hausman tersebut diketahui nilai probabilitas Chi square statistik 0.0000. Dengan tingkat signifikansi $\alpha$ sebesar 5\% maka $\mathrm{aH}_{0}$ ditolak. Artinya model fixed effect lebih baik digunakan dibandingkan menggunakan model random effect. Karena setelah melakukan pengujian model dengan uji hausman diperoleh model fixed effect lebih baik, maka tidak perlu lagi dilakukan pengujian lebih lanjut, maka dapat disimpulkan bahwa model regresi data panel yang paling tepat digunakan dalam analisis adalah fixed effect model.

\section{Uji Asumsi}

1. Uji Normalitas

Hasil deteksi normalitas dengan menggunakan uji Jarque-Bera yaitu dengan membandingkan nilai Chi Squared tabel. Apabila $J B_{\text {hitung }}<$ Chi Squared tabel maka residual berdistribusi normal. Hasil uji normalitas dengan Jarque-Bera diperlihatkan pada Gambar 1.
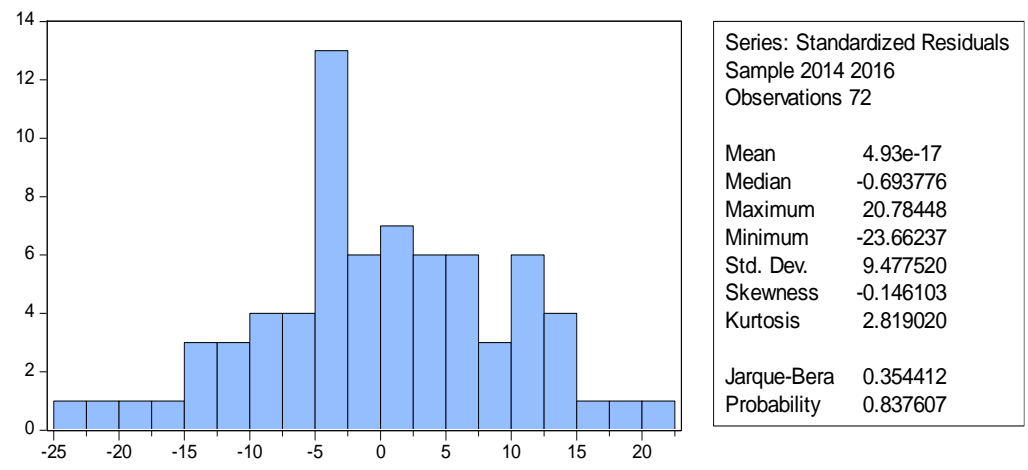

Gambar 1. Hasil Uji Normalitas

Gambar 1 diperoleh nilai $J B_{\text {hitung }}$ dengan melihat nilai Jarque-Bera yaitu sebesar 0.354412 , sedangkan nilai Chi-Squared tabel dengan derajat kebebasan sebesar 5 dan $\alpha=5 \%$ adalah 11.0704977 sehingga nilai $J B_{\text {hitung }}<$ nilai Chi Squared tabel. Berdasarkan perbandingan tersebut dapat disimpulkan bahwa residual persamaan regresi panel dengan model fixed effect memiliki distribusi normal.

2. Uji Heteroskedastisitas

Untuk mengetahui ada tidaknya suatu heteroskedastisitas dalam penelitian ini dilakukan dengan uji glasjer (glasjer test). Pengujian heteroskedastisitas dengan menggunakan uji glasjer dilakukan dengan meregresikan nilai residual dan nilai absolut terhadap seluruh variabel bebas., jika signifikansi $<0.05$ maka terjadi heteroskedastisitas (Adelina, 2016). Hasil Uji Glasjer terdapat pada Tabel 7. 
TABEL 7 Hasil analisis regresi identifikasi heteroskedastisitas dengan Uji Glejser

\begin{tabular}{ccccc}
\hline Variable & Coefficient & Std. Error & t-Statistic & Prob. \\
\hline$X_{1}$ & 0.023873 & 0.020128 & 1.186102 & 0.2421 \\
$X_{2}$ & -0.004381 & 0.005349 & -0.819056 & 0.4173 \\
$X_{3}$ & 1.194979 & 0.861504 & 1.387086 & 0.1726 \\
$X_{4}$ & 0.000662 & 0.001115 & 0.593646 & 0.5559 \\
$X_{5}$ & $4.12 \mathrm{E}-05$ & $3.94 \mathrm{E}-05$ & 1.045280 & 0.3017 \\
$\mathrm{C}$ & -12.90129 & 47.91173 & -0.269272 & 0.7890 \\
\hline
\end{tabular}

Dari hasil uji glasjer yang telah dilakukan pada Tabel 7 diperoleh nilai probabilitas seluruh variabel indenpenden $<0.05$, sehinggan $H_{0}$ ditolak yang berarti tidak terdapat heteroskedastisitas.

3. Uji Multikolinearitas

Uji multikolinearitas dilakukan dengan menghitung koefisien korelasi antara variabel indpenden yang ditampilkan pada Tabel 8 .

TABEL 8. Koefisien korelasi antar variabel bebas

\begin{tabular}{cccccc}
\hline & $\boldsymbol{X}_{\mathbf{1}}$ & $\boldsymbol{X}_{\mathbf{2}}$ & $\boldsymbol{X}_{\mathbf{3}}$ & $\boldsymbol{X}_{\mathbf{4}}$ & $\boldsymbol{X}_{\mathbf{5}}$ \\
\hline $\boldsymbol{X}_{\mathbf{1}}$ & 1.000000 & 0.865655 & 0.494296 & 0.820802 & 0.714687 \\
$\boldsymbol{X}_{\mathbf{2}}$ & 0.865655 & 1.000000 & 0.732275 & 0.897250 & 0.727980 \\
$\boldsymbol{X}_{\mathbf{3}}$ & 0.494296 & 0.732275 & 1.000000 & 0.685259 & 0.367794 \\
$\boldsymbol{X}_{\mathbf{4}}$ & 0.820802 & 0.897250 & 0.685259 & 1.000000 & 0.682453 \\
$\boldsymbol{X}_{\mathbf{5}}$ & 0.714687 & 0.727980 & 0.367794 & 0.682453 & 1.000000 \\
\hline
\end{tabular}

Variabel independen dikatakan tidak mengalami multikolinearitas apabila pada matriks korelasi tidak terdapat nilai > 0.90. Pada output Tabel 8 tampak bahwa koefisien korelasi seluruh variabel indpenden $<0.90$ sehingga dapat disimpulkan bahwa persamaan regresi panel dengan model fixed effect tidak mengalami multikolinearitas.

\section{Uji Signifikansi Parameter}

1. Uji Serentak (Uji-F)

Untuk menguji apakah koefisien regresi secara seluruh variabel bebas secara bersamasama atau menyeluruh berpengaruh terhadap variabel terikat perlu dilakukan pengujian dengan mencari nilai $F_{\text {hitung }}$ yang diperoleh pada tabel berikut.

TABEL 9 Hasil Uji-F model fixed effect

\begin{tabular}{|c|c|} 
R-squared & 0.824979 \\
Adjusted R-squared & 0.711012 \\
S.E. of regression & 12.17838 \\
Sum squared resid & 6377.461 \\
Log likelihood & -263.5825 \\
F-statistic & 7.238757 \\
Prob(F-statistic) & 0.000000
\end{tabular}


Hasil uji statistik $\mathrm{F}$ tabel output fixed effect pada Tabel 9 menunjukkan nilai signifikansi F-statistic sebesar 0,00000<0,05 (5\%), sehingga keputusan yang diambil yaitu tolak $H_{0}$ dan dapat disimpulkan bahwa secara bersama-sama variabel $X_{1}, X_{2} . X_{3}, X_{4}$ dan $X_{5}$ berpengaruh secara signifikan terhadap variabel $Y$.

2. Uji Parsial (Uji-T)

Uji-T digunakan untuk menguji koefisien regresi secara individu. Pengujian dilakukan terhadap koefisien regresi populasi, apakah sama dengan nol, yang berarti variabel bebas tidak mempunyai pengaruh signifikan terhadap variabel terikat, atau tidak sama dengan nol, yang berarti variabel bebas mempunyai pengaruh signifikan terhadap variabel terikat.

Berdasarkan hasil perhitungan pada Tabel 7 diperoleh nilai $T_{\text {hitung }}$ yang menunjukkan bahwa pengaruh $X_{1}$ dan $X_{3}$ terhadap variable Y positif dan signifikan.

3. Koefisien Determinasi $\left(R^{2}\right)$

Koefisiensi determinan $\left(R^{2}\right)$ digunakan untuk mengukur kebaikan atau kesesuaian (goodness of fit) suatu model persamaan regresi. Nilai $R^{2}$ menyatakan proporsi variasi dalam variabel dependen dapat dijelaskan oleh variabel independen (Arthati).

Dari Tabel 9 diperoleh nilai $R$-Squared yaitu sebesar 0.824979. Berdasarkan nilai $R$ Squared yang diperoleh dapat diinterpretasikan bahwa variabilitas jumlah kematian bayi di Provinsi Sulawesi Selatan dapat dijelaskan dengan sangat baik oleh variabel prediktor yang berpengaruh yaitu Berat Bayi Lahir Rendah $\left(X_{1}\right)$ dan Penduduk Miskin $\left(X_{3}\right)$ sebesar $82.4 \%$ dan sisanya sebesar $17.6 \%$ dijelaskan faktor lain yang tidak termasuk dalam regresi. Sehingga model regresi data panel fixed effect signifikan terhadap model.

\section{PEMBAHASAN}

Penelitian sebelumnya tentang estimasi parameter model regresi data panel random effect dengan metode generalized least squares (GLS) yang dilakukan oleh Novi Aulia Rizki (2011), Penerapan Regresi Data Panel Komponen Satu Arah untuk Menentukan Faktor-Faktor yang Mempengaruhi Indeks Pembangunan Manusia yang dilakukan oleh Bayu Sutikno dkk (2017), dan Analisis Estimasi Model Regresi Data Panel dengan pendekatan common effect model (CEM), fixed effect model (FEM) dan random effect model (REM) yang dilakukan oleh Styfanda Pangestika (2015).Masing-masing ketiga penelitian diatas menerapkan model random effect dengan metode Generalized Least Squares (GLS) dalam permasalahan pengaruh Kurs terhadap harga saham perusahaan yang tergabung di Jakarta Islamic Index (JII), kedua peneliti Bayu Sutikno dkk juga menggunakan model random effect untuk menentukan faktor-faktor yang mempengaruhi Indeks Pembangunan Manusia (IPM), sedangkan Styfanda melakukan pemodelan Indeks Pembangunan Manusia (IPS) di Kabupaten/Kota di Jawa Tengah tahun 2008-2012 dengan mengestimasi ketiga model regresi panel dan menyimpulkan bahwa model terbaik yang digunakan dalam penelitian tersebut adalah model fixed effect.Pada penelitian ini diterapkan regresi data panel pada pemodelan jumlah kematian bayi di Provinsi Sulawesi Selatan tahun 2014-2015. Penelitian ini bertujuan untuk mendapatkan model terbaik dari jumlah kematian bayi dan mengetahui faktor-faktor yang berpengaruh secara signifikan terhadap jumlah kematian bayi di Provinsi Sulawesi Selatan tahun 2014-2016. Berdasarkan hasil yang diperoleh menunjukkan bahwa faktor-faktor yang berpengaruh secara signifikan terhadap jumlah kematian bayi adalah Bayi Berat Lahir Rendah (BBLR) dan jumlah penduduk miskin.

Setelah didapatkan masing-masing model untuk regresi data panel kemudian dilakukan uji untuk menentukan model yang tepat digunakan dalam analisis menggunakan uji chow dan uji hausman. Kesimpulan yang diperoleh bahwa model fixed effect lebih baik dari common effect 
dan random effect. Setelah diperoleh model terbaik selanjutnya dilakukan uji asumsi yang harus dipenuhi oleh model regresi data panel yaitu asumsi normalitas, asumsi multikolinearitas dan asumsi heteroskedastisitas. Hasil uji normalitas disimpulkan bahwa residual persamaan regresi panel dengan model fixed effect memiliki distribusi normal. Sedangkan hasil pemeriksaan multikolinieritas disimpulkan bahwa persamaan regresi panel dengan model fixed effect tidak mengalami multikolinearitas sehingga semua variabel dapat digunakan untuk model regresi data panel. Uji asumsi yang terakhir yaitu pengujian heteroskedastisitas nilai signifikansi seluruh variabel independen > 0.05 sehingga tidak terjadi heteroskedastisitas. Model regresi tiap kabupaten/kota di Provinsi Sulawesi Selatan tahun 2014-2016 menunjukkan bahwa kematian bayi di wilayah kabupaten Bone dan Kabupaten Jeneponto memiliki jumlah kematian yang tinggi. Selain itu berdasarkan uji hipotesis diperoleh nilai $R$-Square sebesar $82 \%$. Berdasarkan nilai $R$-Squared yang diperoleh dapat diinterpretasikan bahwa variabilitas jumlah kematian bayi di provinsi Sulawesi Selatan tahun 2014-2016 dapat dijelaskan dengan sangat baik oleh variabel prediktor yang berpengaruh yaitu BBLR dan penduduk miskin.

Hasil uji hipotesis yaitu uji T menunjukkan bahwa variabel $X_{1}$ dan $X_{3}$ berpengaruh positif dan signifikan terhadap model. Selanjutnya berdasarkan uji serentak (uji F) diketahui bahwa minimal ada satu variabel prediktor yang berpengaruh signifikan terhadap model.

\section{KESIMPULAN}

Berdasarkan hasil penelitian dan pembahasan pada bab sebelumnya dapat disimpulkan bahwa

1. Setelah memenuhi uji asumsi dan pemeriksaan koefisien model regresi, maka model regresi data panel yang lebih sesuai untuk pemodelan jumlah kematian bayi di seluruh Kabupaten/Kota di Sulawesi Selatan dari tahun 2014 sampai dengan 2016 adalah Fixed Effect Model (FEM).

2. Hasil estimasi analisis regresi data panel dengan model fixed effect adalah sebagai berikut

$$
\hat{Y}_{i t}=\hat{\mu}_{\mathrm{it}}+129.4412-0.146037 \mathrm{X}_{1_{\mathrm{it}}}-5.924979 X_{3_{i t}}
$$

3. Dari hasil analisis regresi data panel dengan model fixed effect didapatkan bahwa variabel bayi berat lahir rendah $\left(\mathrm{X}_{1}\right)$ dan jumlah penduduk miskin $\left(\mathrm{X}_{3}\right)$ secara bersamasama mempengaruhi variabel jumlah kematian bayi sebesar $82.4 \%$ sedangkan sisanya sebesar $17.6 \%$ dijelaskan oleh variabel lain diluar model.

4. Berdasarkan hasil penelitian diperoleh estimasi parameter model regresi data panel terbaik dengan pendekatan Fixed Effect Model (FEM) yang selanjutnya dapat digunakan untuk memperkirakan nilai-nilai populasi pada Angka Kematian Bayi (AKB. Sehingga untuk peneliti berikutnya yang secara khusus membahas mengenai estimasi model regresi data panel diharapkan dapat menganalisis secara detail mengenai pemilihan model regresi data panel terbaik yang salah satunya adalah menggunakan model common effect dan random effect dalam berbagai permasalahan di bidang kesehatan maupun bidang lainnya.

\section{DAFTAR PUSTAKA}

Adelina, R.R. (2016). Model Prediksi Jumlah Kematian Ibu dengan Aplikasi Regresi Panel di Jawa Timur 2009-2014. (Skripsi, tidak dipublikasikan). Universitas Airlangga, Surabaya.

Gujarati N. Damodar. (2004). Basic Econometrics. 4th Edition. New York-USA:McGraw-Hill. Gujarati, Damodar N. (2006). Ekonometrika Dasar. Jakarta : Penerbit Erlangga. 
Pangestika, S. (2015). Analisis Estimasi Model Regresi Data Panel dengan Pendekatan Common Effect Model (CEM), Fixed Effect Model (FEM) dan Random Effect Model $(R E M)$. (Skripsi, tidak dipublikasikan). Universitas Negeri Semarang, Semarang.

Sutikno, B., Faruk, A., Dwipurani, O. (2017). Penerapan Regresi Data Panel Komponen Satu Arah untuk Menentukan Faktor-Faktor yang Mempengaruhi Indeks Pembangunan Manusia. Jurnal Matematika Integratif. 13(1): 1-10.

Widarjono, A. (2009). Ekonometrika Pengantar dan Aplikasinya. Yogyakarta:Ekonisia. 